JAN SAMEK

\title{
ZABYTKI KULTU ŚWIĘTEGO WOJCIECHA W KRAKOWIE
}

Minął rok 1997, rok jubileuszowej śmierci, patrona Polski - świętego Wojciecha. W tym roku miały miejsce liczne uroczystości, głównie w Gnieźnie, tam bowiem zachowały się najcenniejsze zabytki związane $\mathrm{z}$ tym świętym, wśród nich zdobione scenami z jego życia.

Mamy tu na myśli przede wszystkim romańskie drzwi z brązu powstałe około roku 1133 (?) z przedstawieniami z życia świętego i jego męczeństwa, a jest to najwcześniejszy i największy cykl tego rodzaju. Drugim wybitnym dziełem tego rodzaju jest relikwiarz na głowę świętego Wojciecha (skradziony w okresie międzywojennym), któremu zamierzamy poświęcić osobną rozprawe.

Relikwiarz ten, ośmioboczny, kopułowy wykonany został ze złota, przy bogatej kameryzacji, z rytami ze scenami z życia świętego Wojciecha na ściankach bocznych. Znany jest autor, nawet $w$ archiwach sa informacje o wykonaniu relikwiarza: był nim poznański złotnik Jakub Barth. Relikwiarz był kameryzowany przy pomocy szafirów i pereł, wysokość wynosiła 22,1 $\mathrm{cm}$, obwód $71,2 \mathrm{~cm}$.

$\mathrm{Na}$ szczęście zachowała się kopia sprzed roku 1923, przechowywana w Muzeum Narodowym w Poznaniu.

Z kolei wymienić można srebrną trumnę z XVII wieku, mieszczącą zwłoki zmarłego, także w katedrze Gnieźnieńskiej. Powstała ona w Gdańsku z fundacji księdza Wojciecha Pilchowicza, kanonika gnieźnieńskiego, sufragana warneńskiego. Relikwiarz wykonany jest ze srebra, ma duże rozmiary, $131 \times 159 \times 53 \mathrm{~cm}$.

Autorami byli bardzo znany złotnik Piotr van Rennen i Jan Hans Paweł Jung, obaj czynni w Gnieźnie. Należy dodać, że wymieniona trumna, łącznie z trumną świętego Stanisława (także srebrna) w Krakowie, również dzieło Piotra van Rennenma, jako daleki pierwowzór (co jest hipoteza), duże romańskie znacznie wcześniejsze relikwiarze świętych licznie zachowane na terenie Niemiec. Trumna gnieźnieńska ozdobiona jest licznymi scenami z życia świętego Wojciecha oddanymi w płaskorzeźbie. 
Powracając do Krakowa w roku jubileuszowym świętego Wojciecha, poświęcono patronowi Polski tylko niewielką wystawę, w pozostających w gestii Muzeum Archeologicznego, podziemiach kościoła świętego Wojciecha (tzw. krypcie konserwatorskiej). Ukazano tam głównie duże reprodukcje ze scenami z życia świętego Wojciecha z drzwi gnieźnieńskich.

Czas więc najwyższy, aby krakowskim zabytkom związanym $\mathrm{z}$ tym tak popularnym w Polsce świętym poświęcić osobne omówienie, bo są one tego warte.

\section{KOŚCIÓŁ}

Kościół Świętego Wojciecha w Krakowie, umieszczony w pd.-zach. części rynku, posiada dawną proweniencję. Jak wykazały prace archeologiczne, główna budowla usytuowana mniej więcej w tym miejscu co obecna, była drewniana i datuje się ją na $X$ wiek. Kolejny murowany kościół z wieżą powstał zapewne $w$ dwóch fazach, jednak obecny ( $\mathrm{z}$ nie zachowaną wieża) odnosi się do początku wieku XII. W zasadniczej bryle jako budowla jednonawowa z nawą prostokątną, w której ścianach wschodnich znajdują się nisze „zastępujące" apsydy, budowla dotrwała do dziś. W czasie prac prowadzonych jeszcze w dawniejszym okresie konserwatorskim odkryto partie romańskie, które zostały przy późniejszych konserwacjach po drugiej wojnie światowej poszerzone. Kościół był prebenda Akademii Krakowskiej. Przypomnijmy, że bardziej związana z uniwersytetem była Kolegiata Sw. Anny, także do uniwersytetu należały, pozostając pod jego opieką kościoły Św. Floriana, w którym zachowały się liczne pamiątki po profesorach i Św. Mikołaja.

Gruntownej przebudowie uległ kościół Świętego Wojciecha w czasach nowożytnych w latach 1611-1616. Inicjatorem był profesor Akademii Krakowskiej Walenty Fontana. Nieznany, bardzo zdolny architekt zamienił niewielki kościółek w okazałą kaplicę o formach barokowych bardzo wczesnych właściwie jak na te czasy, gdy jeszcze nie była wykonana fasada kościoła ŚŚ. Piotra i Pawła w Krakowie, który pozostawał od końca XVI wieku w budowie.

Formy wczesnobarokowe wyrażają się w akcentowaniu narożników budowli silnym boniowaniem oraz dużych okragłych, także ujętych $\mathrm{w}$ boniowanie, oknach. Przy siedemnastowiecznej przebudowie znacznie podwyższono mury, podniesiono poziom posadzki. Dodajmy, że przebudowa ta miała miejsce przy udziale prepozyta Sebastiana Mirosza. Zamiast sklepienia kolebkowego zastosowano, chyba pierwszą tego typu w Krakowie, wynikająca $\mathrm{z}$ prostokątnego planu nawy, lekko owalną kopułę na pendentywach, która ma zwieńczenie $w$ formie latarni. Trzeba tu powiedzieć, że mimo opracowania kaplic kopułkowych w Polsce w książce „Grobowe kaplice kopułkowe w Polsce 1520-1620" istnieje bardzo dużo luk w omówieniu tego zagadnienia. Otóż nie pisze się szerzej o kaplicach nawiązujących, niewąt- 
pliwie w dużym stopniu, w formie do Kaplicy Zygmuntowskiej na Wawelu, (która posiada okragłe okna i kopułę), nie o mauzoleach, lecz o kaplicach kultowych.

Można wydzielić, o czym warto w tym miejscu powiedzieć, kilka rodzajów kaplic, których nie koniecznie rozpoznawalną cechą jest kopuła: kaplice mauzolea, królewskie, magnackie i mieszczańskie, wreszcie poświęcone Matce Boskiej, wybitnym świętym i błogosławionym, począwszy od zygmuntowskiej (po 1537). Należy tu m.in. nie zachowana do naszych czasów w pierwotnej formie kaplica Św. Jacka, kaplica błogosławionej Salomei, $\mathrm{z}$ czasu po 1675 , wreszcie kaplice ściśle kultowe, niezwiązane z pomnikiem nagrobkowym (Kraków kościół Karmelitów Bosych na Piasku, Myślenice, Branice, Niepołomice).

Otóż te kaplice ściśle kultowe występują bardzo wcześnie. Przykładem kaplica w Miechowie, która poświęcona jest Grobowi Świętemu, a w obecnej formie pochodzi z czasu poświęcenia Kaplicy Zygmuntowskiej (1533), bowiem datuje ją portal na rok 1534 .

Nie podejmując szeroko tego zagadnienia, które pragnę rozszerzyć gdzie indziej, wspomnę, że kolejne kaplice o czym będzie mowa przy omawianiu kaplicy Matki Bożej Piaskowej, powstały już w XVII wieku, głównie jako kaplice Maryjne.

Warto jeszcze zwrócić uwage, że inicjatorem przebudowy kościoła Św. Wojciecha był Walenty Fontana, wybitny uczony, sześciokrotny rektor Akademii Krakowskiej, pochodzący ze Śląska, który co jest istotne dla budowy kościoła Św. Wojciecha był matematykiem, lekarzem, wykładał nauki ścisłe, zaś w latach 1587-1588 trygonometrię, a interesował się też astrologią.

Byłoby bardzo interesującym, co w przyszłości zamierzamy zrobić, rozważanie problemu zastosowania elipsy do rzutu kopuły i porównaniem tego zagadnienia $\mathrm{z}$ rozwojem nauk nad geometrią w Krakowie.

Warto przypomnieć, że dalsze kaplice o kopułach owalnych wyznacza kaplica Zbaraskich przy kościele Dominikanów w Krakowie (1627-1633), następnie kaplice przy kolegiacie Św. Anny, (po 1692), środkowe, właściwie pełniące rolę naw bocznych, w kościele Św. Andrzeja (1700-1702), wreszcie kaplice owalne stosowano w późniejszych kościołach w XVIII wieku, które projektował Kacper Bażanka i Franciszek Placcini, u Misjonarzy na Stradomiu i u Bonifratrów.

Rozwój form kopułowych to jednak osobne zagadnienie.

W dalszych dziejach kościoła Św. Wojciecha kult męczennika zawsze się zaznaczat, ale przybyły i inne cechy oddające duchowość tego czasu. Objawami nowego kultu, było wzniesienie przy kościele Św. Wojciecha od południa nowej kaplicy Sw. Jana Nepomucena w roku 1729, którą zamieniono na murowaną w roku 1778 , a także kult św. Onufrego.

Kult św. Jana Nepomucena w Krakowie objawił się licznymi kaplicami przy kościołach, na przykład przy kościele Pijarów, i Paulinów na Skałce. W Polsce kult ten jest wyraźny w XVIII wieku w licznych kapliczkach wznoszonych nad woda. 
Ciekawa jest zmiana wezwania kaplicy Św. Jana Nepomucena na Bł. Wincentego Kadłubka, którego kult, jak wiadomo, rozwijał się w kościele cysterskim w Jędrzejowie. W Krakowie przy kościele Św. Wojciecha, jak wspomniano św. Jan Nepomucen otrzymał kaplicę murowana.

Nie wiemy w jakim stopniu odbił się kult św. Wojciecha w polichromii, jaką ozdobił wnętrze kościoła w latach 1758-1759 Andrzej Radwański, znany malarz-freskant czynny w Krakowie, a także w Jędrzejowie.

W każdym razie w XVIII stuleciu, trzymając się prac związanych $\mathrm{z}$ architektura, powstał portal główny, datowany na 2 poł. wieku XVIII, wykonany $\mathrm{z}$ kamienia dębnickiego, inkrustowanego marmurem paczułtowickim, ozdobiony płaskorzeźbą św. Wojciecha i dwóch aniołów, z jego atrybutami w części górnej.

Cofnąć się teraz należy, porzucając już architekturę, do przedstawień św. Wojciecha w innych dziedzinach.

\section{ŚWIĘTY WOJCIECH W KRAKOWIE, W GOTYCKIM MALARSTWIE DESKOWYM I RZEŹBIE}

Poszukując przedstawień św. Wojciecha w naszym mieście, zauważamy przede wszystkim, że występuje on w malarstwie, są to wyobrażenia jednopostaciowe $\mathrm{z}$ atrybutami, jakimi są: strój biskupi i wiosło, lub krzyż, czasem podwójny. Zwrócić się tutaj należy ku malarstwu sztalugowemu. Za przykład występowania w nim właśnie tego typu przedstawień patrona moga posłużyć na razie dwa zabytki. Pierwszy z nich to dwa duże skrzydła ołtarzowe, datowane na czas około $1470 \mathrm{w}$ katedrze na Wawelu. Umieszczono na nich, na złotym tle, w pontyfikalnych strojach biskupich, heraldycznie na prawo - jak się domyślamy, bo ołtarz zachowany jest w formie niekompletnej - św. Wojciecha, z lewej - św. Stanisława biskupa i męczennika. Obaj święci występuja w infułach, chociaż w czasach, w których żyli infuł jeszcze nie używano.

Święty Stanisław biskup przedstawiony został z racjonałem i pastorałem, natomiast święty Wojciech z krzyżem, co łączy się z powtarzaną informacją, że uważany był za biskupa gnieźnieńskiego.

Natomiast w kościele Świętego Krzyża w Krakowie, zachowały się dwa późnogotyckie skrzydła ołtarzowe, datowane na początek XVI wieku. Stanowiły one być może retabulum wraz $\mathrm{z}$ obrazem Zwiastowania, namalowanym przez mistrza Jerzego, który to obraz przechowywany jest w Muzeum Narodowym w Krakowie. Ołtarz ten pochodził, rozdzielony, na muzeum i kościół, z nie zachowanego kościoła Św. Michała na Wawelu.

Późnogotyckie skrzydła ołtarzowe z kościoła Świętego Krzyża, dwustronnie pokryte malowidłami, mieszczą na jednej z kwater świętych: Stanisława i Wojciecha z wiosłem.

Trudno wskazać przedstawienia św. Wojciecha w gotyckiej rzeźbie, niechaj tutaj zadowoli czytelnika wskazanie dużego wyobrażenia świętego wraz 
ze świętym Stanisławem biskupem w kościele Mariackim w zwieńczeniu ołtarza głównego, który powstał w latach 1477-1489 w warsztacie Wita Stwosza. Do tych przedstawień można by dodać znane $\mathrm{z}$ wyobrażenia patronów Polski ze świętym Wojciechem w graficie. Te wybrane przykłady będziemy mogli z pewnością wzbogacić $\mathrm{z}$ terenu oddziaływania sztuki Krakowa.

\section{ŚWIĘTY WOJCIECH W MALARSTWIE I RZEŹBIE CZASÓW NOWOŻYTNYCH}

Okres ten przyniósł rozpowszechnienie i przede wszystkim samodzielne rozwiązania, wizerunki i sceny wieloosobowe z życia świętego Wojciecha. Najczęściej jednak nadal święty Wojciech biskup występuje ze świętym Stanisławem męczennikiem w „parach" w rzeźbie, związanych często tak jak to ma miejsce ze świętym Piotrem i Pawłem tematycznie z ołtarzami.

Takie pary posagów, wyjatkowo pięknych, o dużej wartości artystycznej wykonał przykładowo wybitny mistrz Baltazar Fontana w roku 1701, ustawiono je przed okazałym ołtarzem głównym w świeżo wzniesionej kolegiacie Św. Anny w Krakowie.

Kompozycję tę w drewnie powtórzono około połowy XVIII stulecia w kościele Św. Wojciecha w Krakowie. Niestety w czasie ostatniej konserwacji w wyniku niezrozumienia późnobarokowej koncepcji, „repliki” samodzielnie ustawionych posagów przed ołtarzem w kolegiacie Św. Anny, u Świętego Wojciecha zostały przeniesione na retabulum przez co zatracono pierwotny sens założenia.

W malarstwie krakowskim XVII i XVIII wieku wątkiem męczeńskiej śmierci świętego Wojciecha zajmowali się znani i nieznani malarze, ale zawsze wybitni.

Nieautoryzowanym jest duży obraz znajdujący się w lewym ołtarzu bocznym (1636), usunięty w czasie remontu kościoła Świętego Wojciecha. Bliżej zająłem się nim w pracy o nawrocie gotyku w sztuce barokowej. Jego nieznany, najpewniej cechowy autor, hołdował jeszcze gotyckim tradycjom, albo do nich nawiązywał, przedstawiając męczennika na złotym grawerowanym tle. Malowidło przedstawia ponadto w tle „strącenie bałwana" i „nawracanie pogan" (biskup ukazany jest oczywiście w stroju pontyfikalnym), i należy do jednych $\mathrm{z}$ najciekawszych obrazów naszego patrona $\mathrm{z}$ wczesnych lat XVII wieku.

Natomiast w roku 1649 powstał duży obraz w formie leżacego prostokąta, wielopostaciowy, przedstawiający męczeństwo świętego Wojciecha, zachowany wśród kolekcji malowideł klasztornych u Dominikanów w Krakowie.

Za autora obrazu uznaje się Antoniego Noceniego; malarz ten, co warto wspomnieć, jest także autorem okazałego malowidła przedstawiającego wizje świętego Jacka w kościele Dominikanów w Sandomierzu, poświęcić mu zamierzamy osobną monografię. 
Męczeństwo świętego Wojciecha u Dominikanów to obraz bardzo ekspresyjny, ukazujący cała dzikość pogan zadających śmierć świętemu Wojciechowi i winien być z całą pewnością po starannej konserwacji rozpowszechniany $w$ postaci reprodukcji. Trzeci wybitny obraz świętego Wojciecha z czasów późnego baroku jest dziełem najbardziej znanego polskiego malarza, czynnego w XVIII wieku, którym był Tadeusz Kuntze, nazywany też Koniczem, działający w Rzymie.

Wykonane w roku 1754 malowidło posiada pionową kompozycję i przedstawia męczeństwo świętego Wojciecha, powstało ono dla katedry na Wawelu (dziś znajduje się w zakrystii).

Malowidło Konicza, równie ekspresyjne, w odmienny sposób ukazuje w późnobarokowej konwencji śmierć męczennika. Warto przypomnieć, że Konicz ozdobił znakomitymi malowidłami kościół Misjonarzy na Stradomiu, Paulinów „na Skałce" i jest autorem jednego z portretów biskupich, Andrzeja Stanisława Kostki Załuskiego, który się nim opiekował. Przypominając też, że w XVIII wieku kompozycją Tadeusza Konicza posłużył się, jako wzorem w przedstawieniu Świętego Wojciecha, autor obrazu w kościele parafialnym w Kijach w Kieleckiem.

Przechodząc do innych dziedzin sztuki, w XVIII stuleciu powstał w Krakowie obok innych ufundowany dla kościoła Świętego Wojciecha, niezmiernie oryginalny relikwiarz, który sprawił w roku 1752 Lukasz Jakubowicz; ostensorium odnowiono w roku 1830.

Relikwiarz ten posiada kształt legendarnego herbu świętego - Poraj, którym był wielopłatkowy kwiat róży (zaznaczyć tu trzeba, że w czasach kiedy żył święty Wojciech, herby jeszcze były w Polsce nieznane).

Relikwiarz ten można porównać do rzadko spotykanych monstrancji w formie róży między innymi ze Śmigla czy Strumienia, która ma tam jednak jak sądzimy inną, eucharystyczną symbolikę, choć męczeński aspekt świętego Wojciecha upoważnia dostrzec podwójną symbolikę w tym relikwiarzu, jako herbu i jako symbolu męczeństwa.

Warto też, posuwając się dalej w rozważaniach nad motywem róży, które ma osobne omówienie $\mathrm{w}$ związku z pracami nad ikonografią przedstawień „Świętej Róży Limańskiej”, którymi zajmowała się doktor Beata Frey-Stecowa, przypomnieć kielich o stopie w formie róży (XVII wiek) przechowywany w Muzeum Narodowym w Krakowie.

Reasumując, zabytki związane ze świętym Wojciechem w Krakowie są dość liczne i rozmaite. Należy wątpić, czy w roku jubileuszowym zostały one w odpowiedni sposób zbadane, udosteñnione i rozpropagowane

Mamy nadzieję, że w skromny sposób, uzupełni ten brak niniejsza praca. 
Bibliografia

Kościoly i klasztory Śródmieścia 1, Katalog Zabytków Sztuki w Polsce IV, Miasto Kraków, cz. II, [red.] Samek J., Bochnak A., Warszawa 1971.

Kościoty i klasztory Śródmieścia 2, Katalog Zabytków Sztuki w Polsce IV, Miasto Kraków, cz. III, [red.] Samek J., Bochnak A., Warszawa 1978.

Samek J., Dzieje zlotnictwa w Polsce, Warszawa 1993.

Samek J., Jaka byla sztuka w Krakowie w epoce baroku, [w:] Sztuka baroku, Kraków 1991.

Samek J., Koncepty w sztuce baroku, Biuletyn Historii Sztuki w Polsce XLII, nr 3/4, 1980.

Samek J., Nawrót do gotyku w sztuce Krakowa pierwszej polowy siedemnastego wieku, Folia Historiae Artium, V, 1968.

Samek J., Ostensoria $w$ formie róży. Na marginesie rozważań nad monstrancja w Strumieniu, Cieszyński Rocznik Muzealny II, 1972.

Samek J., Polskie rzemiosto artystyczne. Czasy nowożytne, Warszawa 1984.

Samek J., Problemy artystyczne $i$ ikonograficzne kaplicy Oświęcimów przy kościele Franciszkanów w Krośnie, krosno 1998.

Samek J., Res - imagines. Ze studiów nad rzemiosłem artystycznym czasów nowożytnych w Polsce (lata 1600-1800), Rocznik Historii Sztuki, zeszyt 8, 1970.

Walenty Fontana, Polski Słownik Biograficzny, t. III, oprac. Birkenmajer A., Kraków 1948-1958. Niniejsza praca była referowana na specjalnym sympozjum naukowym zorganizowanym przez autora w papieskiej Akademii Teologicznej w Krakowie w 1998 roku. 


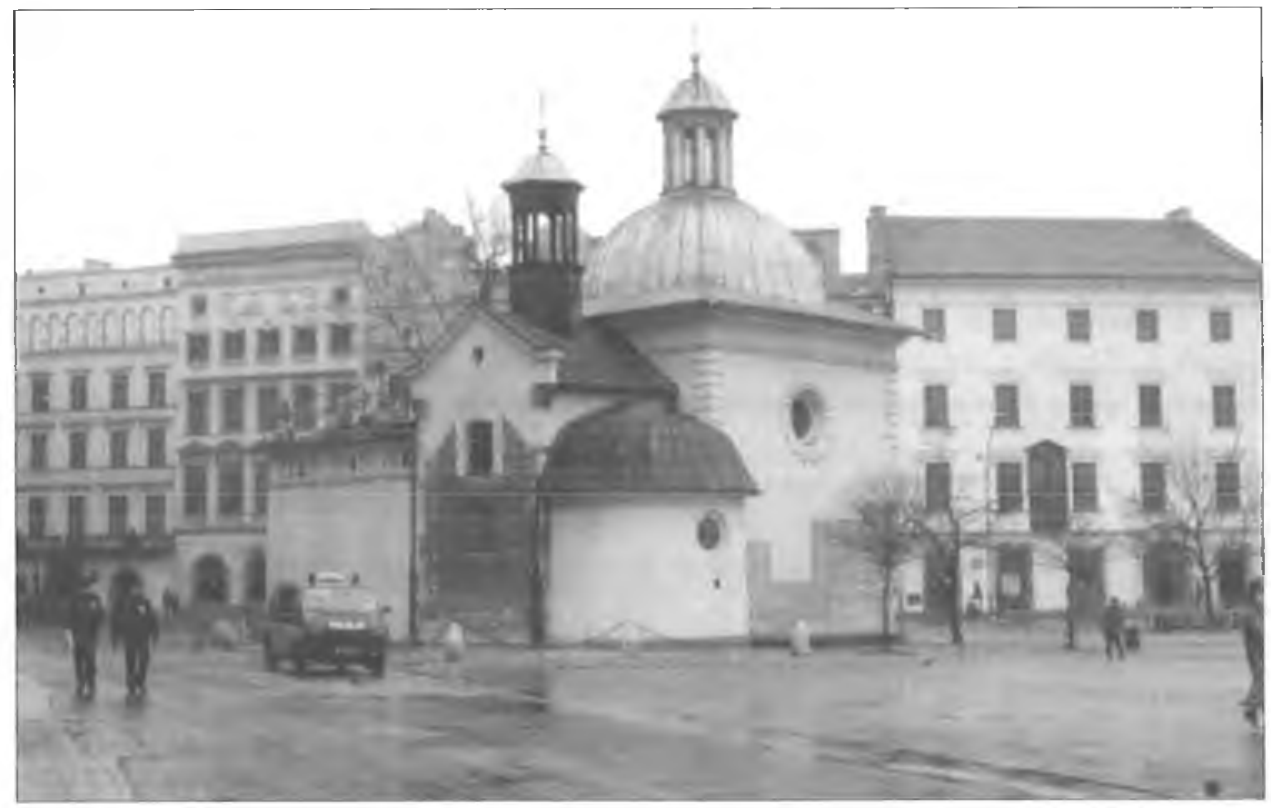

1. Kościół Św. Wojciecha w Krakowie, wid. zewnętrzny od pn.-wsch., fot. M. Samek.

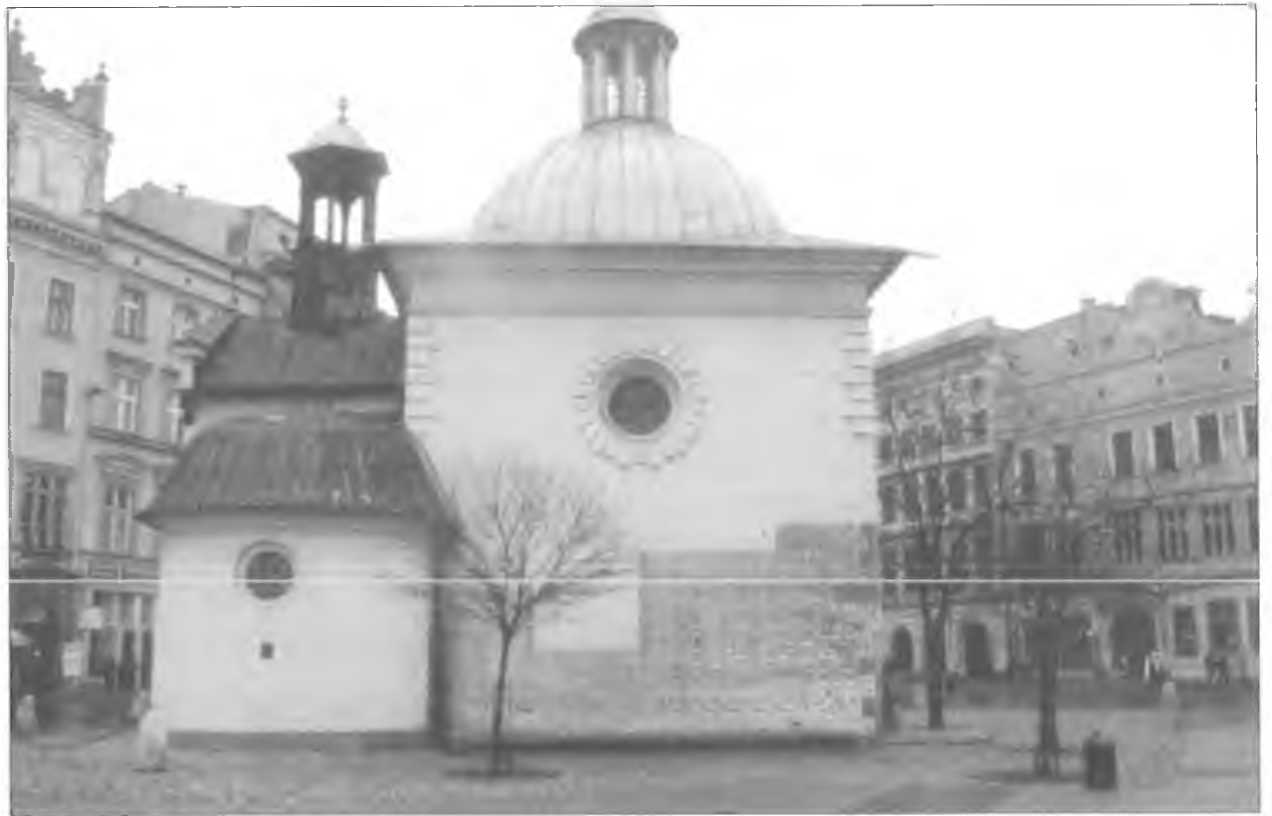

2. Kościół Św. Wojciecha w Krakowie, wid. zewnętrzny od pn., fot. M. Samek. 


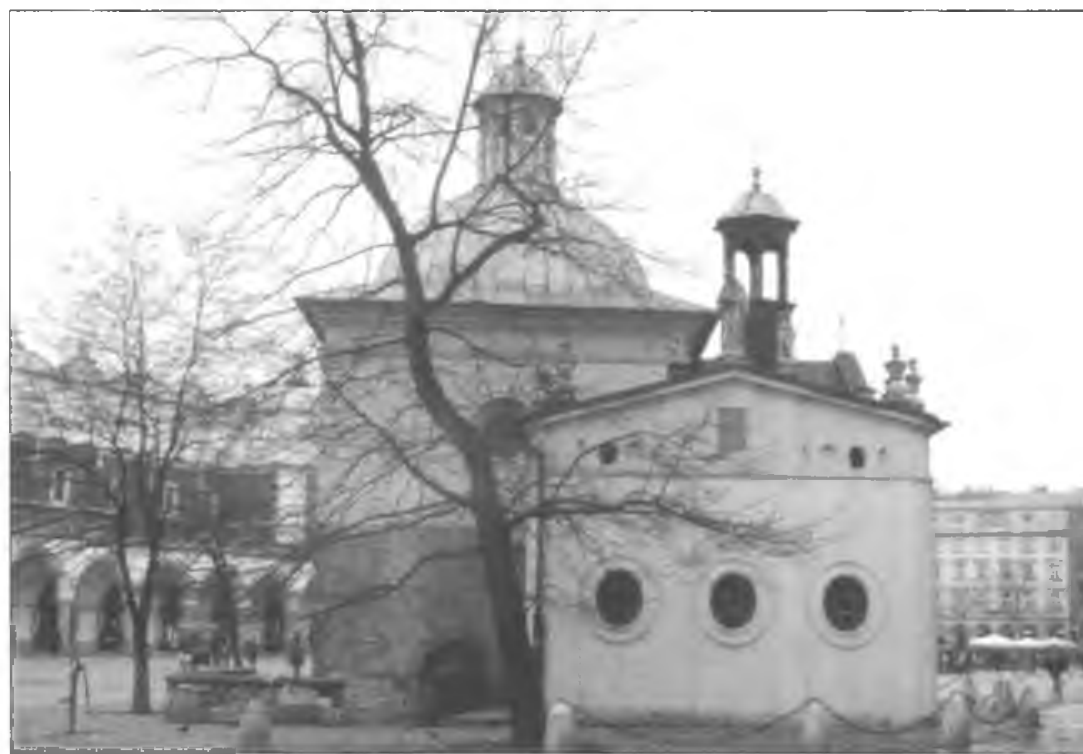

3. Kościół Św. Wojciecha w Krakowie, wid. zewnętrzny od pd. M. Samek. 


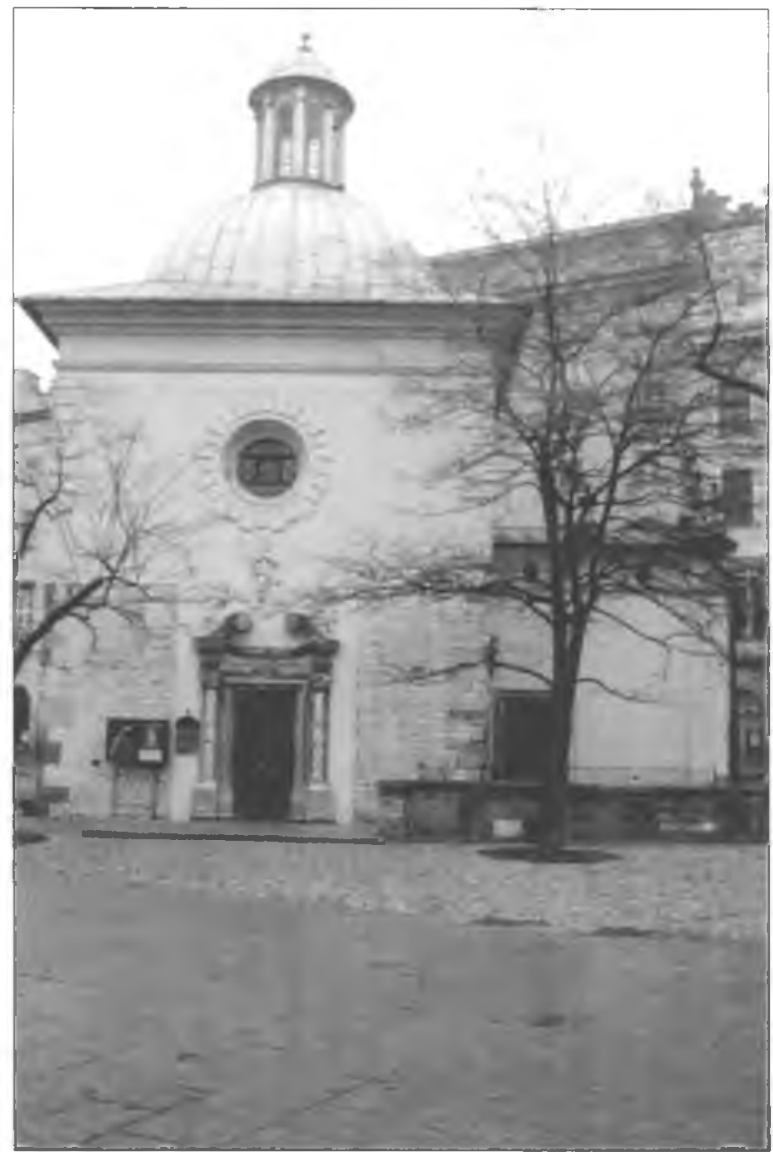

fot. 4. Kościół Św. Wojciecha w Krakowie, wid. Zewnętrzny od zach., fot. M. Samek. 


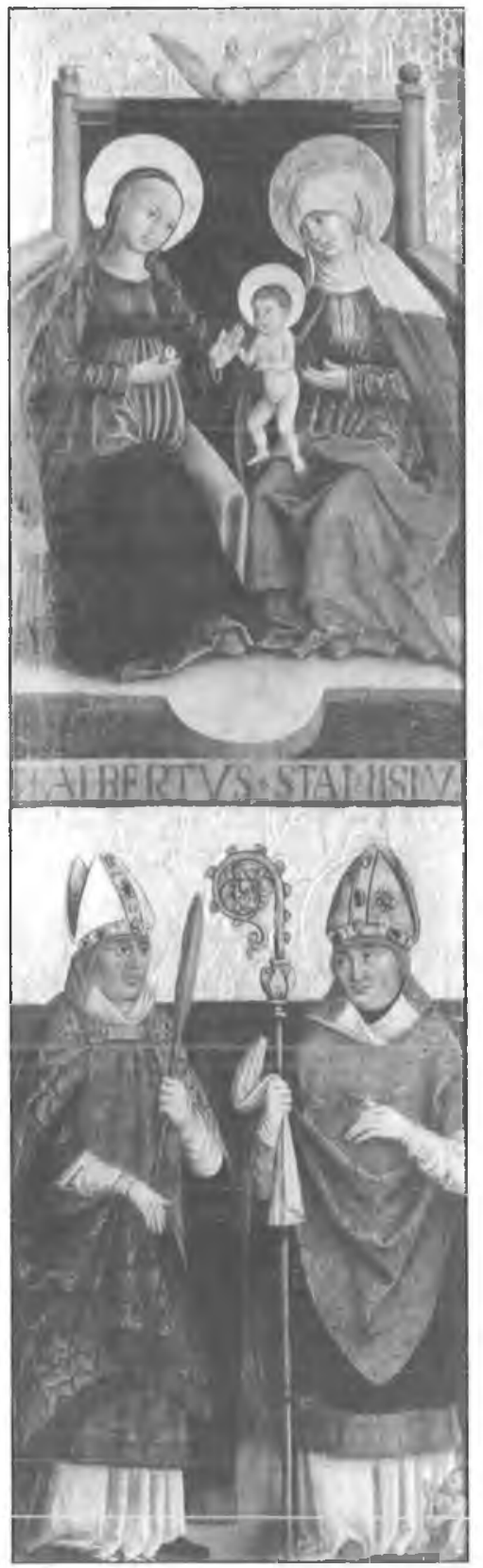

5. Św. Wojciech na skrzydle tryptyku z pocz. XVI w. w kościele Św. Krzyża w Krakowie, wg Katalogu Zabytków...IV/3. 


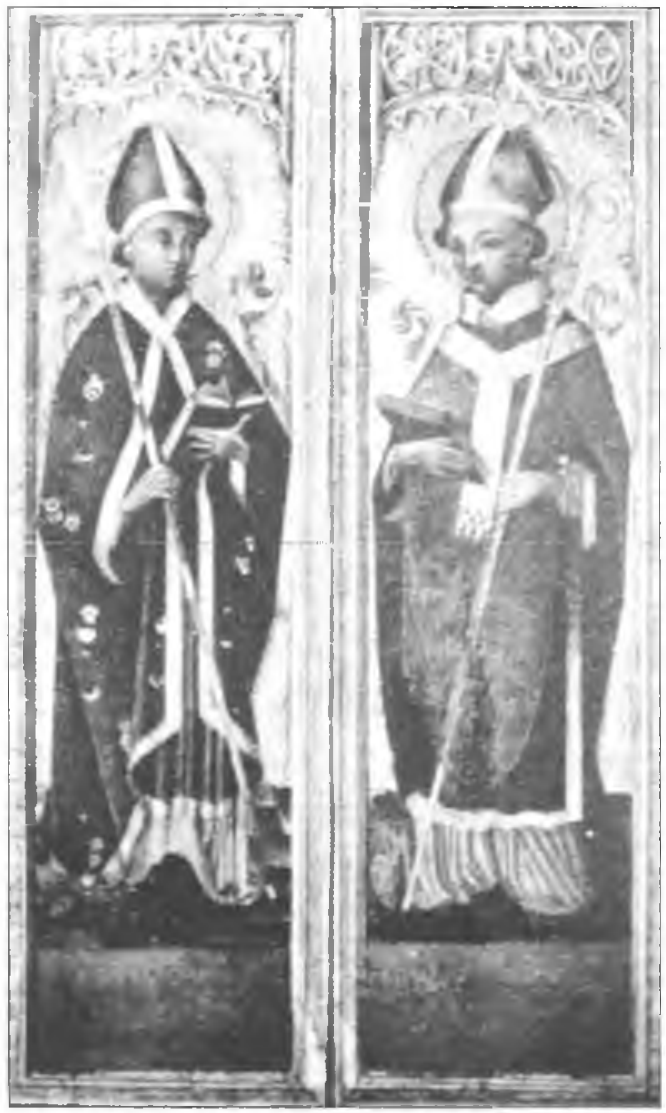

6. Św. Wojciech na skrzydle tryptyku zok. r. 1470 w katedrze na Wawelu w Krakowie, wg Katalogu Zabytków... IV/1. 


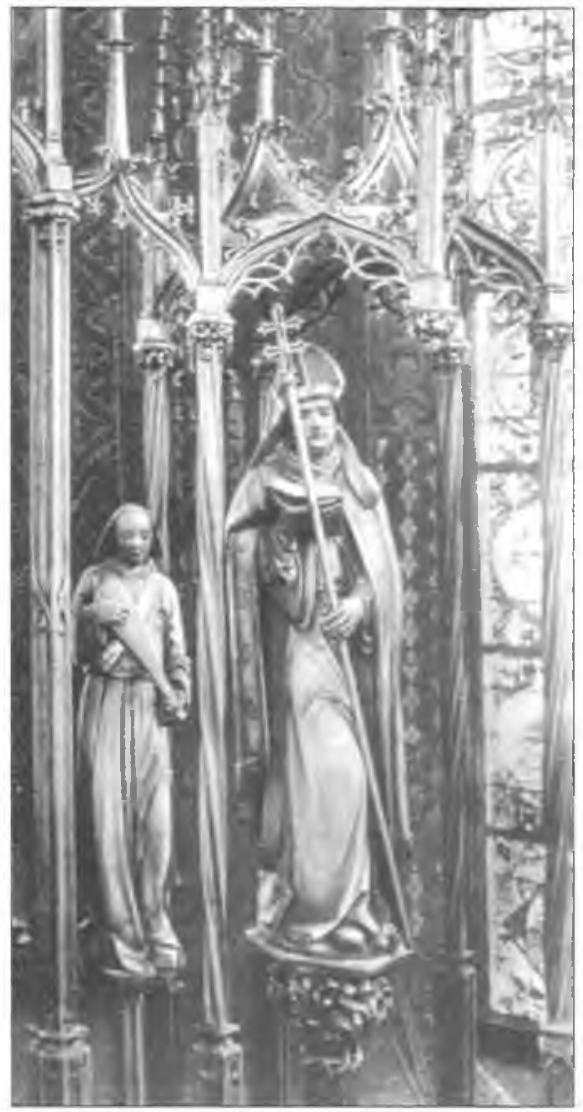

7. Św. Wojciech z ołtarza Wita Stwosza

z 1. 1477-1489 w kościele Mariackim w Krakowie, ze zbiorów autora. 


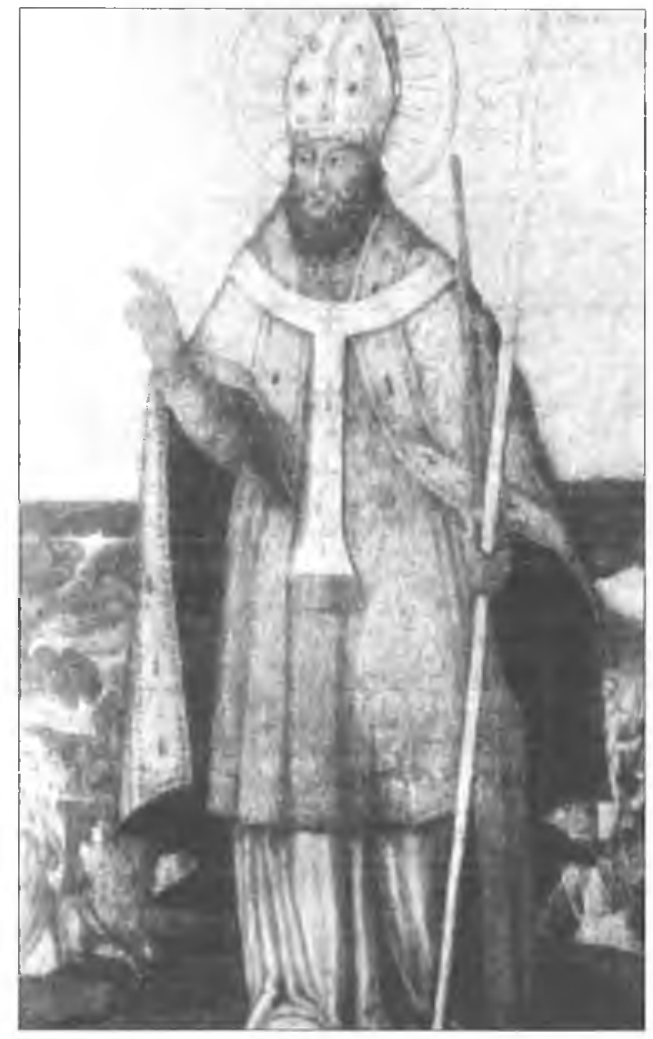

8. Obraz Św. Wojciecha z kościoła Św. Wojciecha w Krakowie, z roku 1636, ze zbiorów autora.

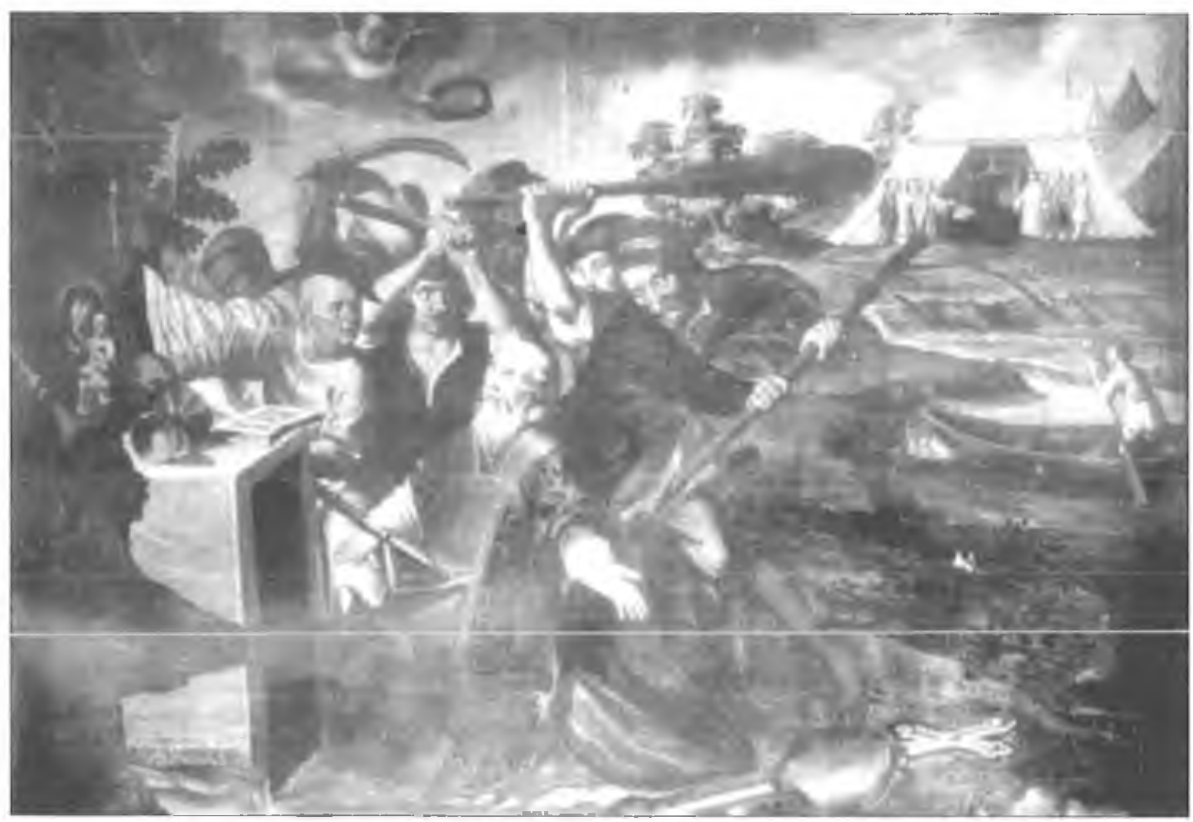

9. Męczeństwo św. Wojciecha, obraz z r. 1649 z kościoła Dominikanów w Krakowie, mal. Antoni Noceni, ze zbiorów autora. 


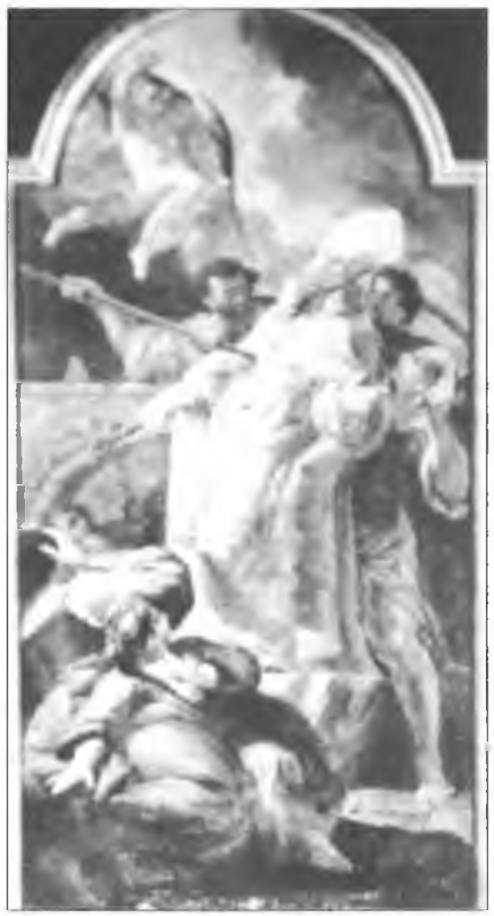

10. Męczeństwo św. Wojciecha, obraz z r. 1754

z katedry na Wawelu w Krakowie, mal. Tadeusz Kuntze, wg Katalogu Zabytków... IV/1.

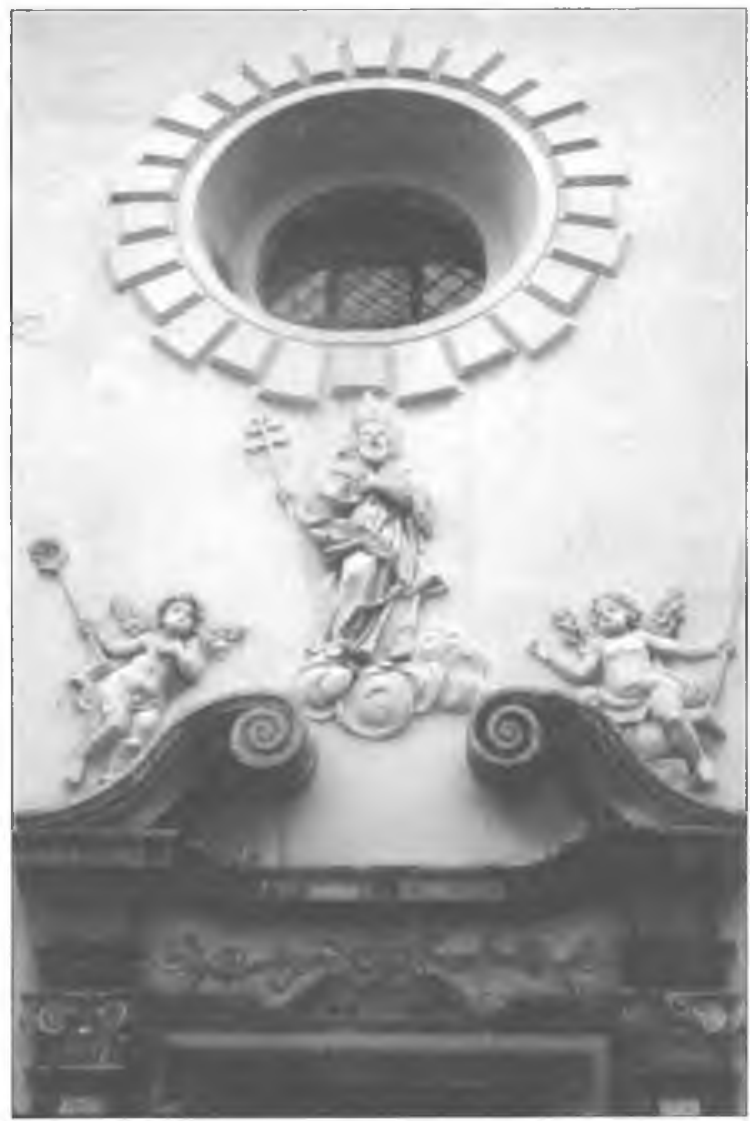

11. Płaskorzeźba nad portalem ze św. Wojciechem z 2 poł. XVIII w. w kościele Św. Wojciecha w Krakowie, fot. M. Samek. 


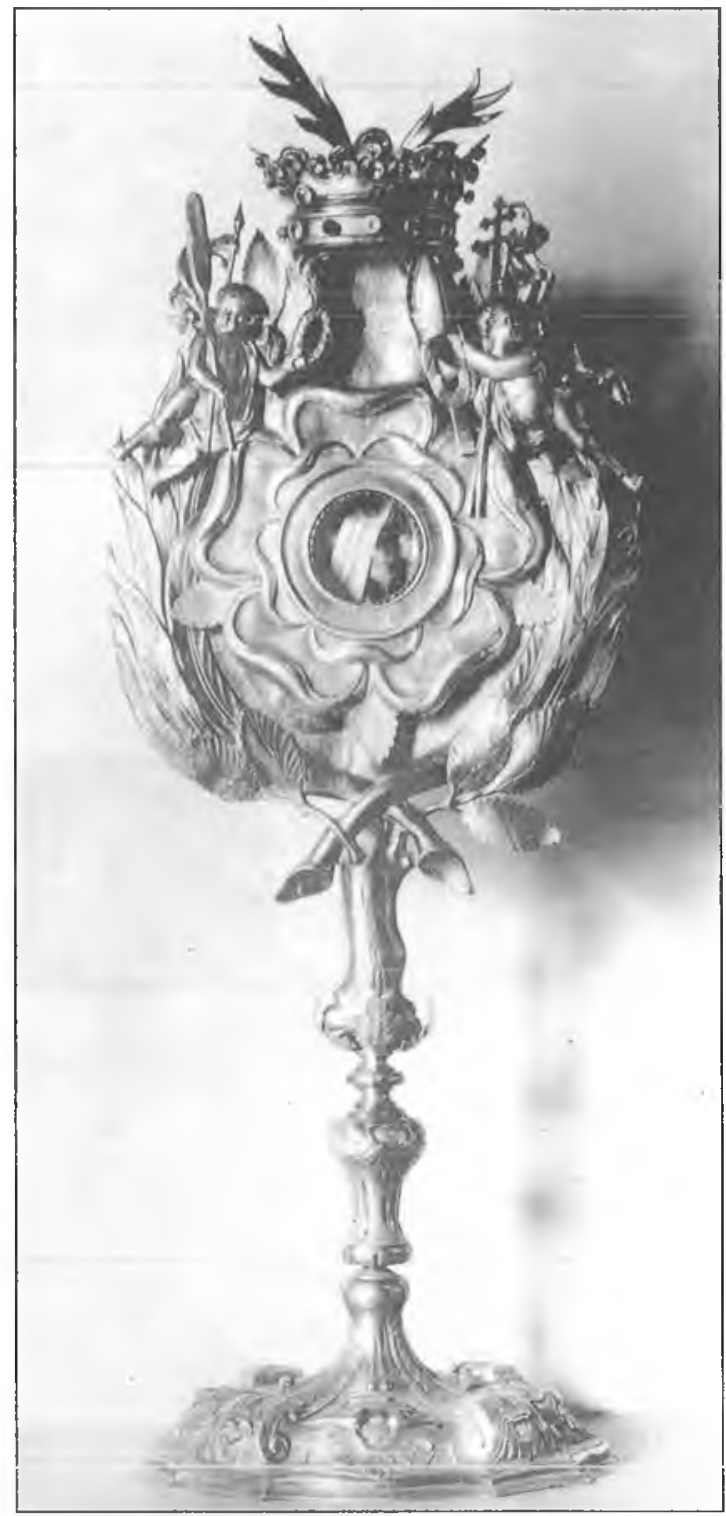

12. Relikwiarz z kościoła Św. Wojciecha z roku 1752 , ze zbiorów autora. 